\title{
Introduction: Visualizing Violence
}

\author{
Mark Hewitson, University College London
}

Few events have been represented with such frequency, exhaustiveness, unevenness and distortion as have wars. In the modern and contemporary eras, which are the focus of this volume, such representation has become largely mediatic and increasingly visual, with the images of photographic journalism, newsreels and television supplementing and contradicting the longer-established genres of military art, monuments, cartoons, treatises, war poems, plays and novels. 'Being a spectator of calamities taking place in another country is a quintessential modern experience', the cumulative offering 'by more than a century and a half's worth of those professional, specialized tourists known as journalists,' writes Susan Sontag in Regarding the Pain of Others (2003):

Wars are now also living room sights and sounds. Information about what is happening elsewhere, called 'news', features conflict and violence - 'If it bleeds, it leads' runs the venerable guideline of tabloids and twenty-four-hour headline news shows - to which the response is compassion, or indignation, or titillation, or approval, as each misery heaves into view. ${ }^{1}$

This impression of knowing 'what happens every day throughout the whole world', with the reports of journalists placing, 'as it were, those in agony on fields of battle under the eyes of readers' and allowing the cries of the wounded to 'resonate in their ears', as the first president of the Red Cross, Gustav Moynier, expressed it in 1899, has been juxtaposed with and opposed to other means of remembering, commemorating and glorifying military conflict, which usually demand separate spaces of reflection, away from the bustle and fragmentation of everyday life. ${ }^{2}$ Here, we ask how wars were visualized in different media, as artists, photographers, film directors and TV producers sought to evoke military conflicts which many had experienced and virtually everyone had 'seen' and 'heard of'.

The relationship between soldiers' and civilians' experiences of warfare and their conceptions of it has been complicated by the clashing imperatives and changing conditions of military conflict. On the one hand, the mediatization of war with the rise of war correspondents and the use of war photography from the Crimean War onwards, for example - combined with mass participation in politics to make governments highly sensitive to press revelations and sensationalism, which they sought to censor, and receptive to the use and abuse of propaganda, which they attempted to instigate and foster. The idea that propaganda was the preserve of the state and involved the presentation and misrepresentation of information in ways 
favourable to one's own country and damaging to enemies owed most to the newly formed agencies of the First World War, such as the British Department (and later Ministry) of Information, before it was taken up by the post-war dictatorships of the 1920 and 1930 and condemned by critics of the Great War like Arthur Ponsonby, whose Falsehood in War-Time: Propaganda Lies of the First World War was published in 1928.3 On the other hand, citizens' direct exposure to warfare had increased as a consequence of conscription and mass mobilization, which had resulted in the military service of more than 80 per cent of men between the ages of twenty and forty-five in Germany and France between 1914 and 1918, and as a result of a widening theatre of operations, with motorized armies and aerial bombardment ensuring that about two-thirds of the casualties in the Second World War were civilians, compared to less than a third of the deaths caused by the First World War.4 Given the stakes, the conflicting claims of different kinds of combatants, victims, journalists, artists, propagandists and officials were bound to create confusion and controversy about the nature of wars, both as they were being waged and as they were later recollected, studied and memorialized. 5 The proximity and disjunction of individuals' experiences, the re-presentation of events, private and public memories, and historical investigation make the interpretation of visual and literary portrayals of wartime violence difficult, but essential, to interpret and explain.

\section{Image and experience}

Ordinary soldiers and civilian victims of war were confronted with unfamiliar and shocking scenes and were pushed into carrying out actions which contravened civilian interdictions and taboos on violence and killing, eliciting extreme emotional reactions and causing psychological breakdowns. ${ }^{6}$ Officially, 613,047 German soldiers (or 4.58 per cent of the total) and 325,312 British troops (5.7 per cent) were listed as psychiatric casualties of the First World War. 7 In the Second World War 1.3 million American servicemen reported psychiatric disorders that were deemed serious enough to warrant their removal from the front line, with 504,000 of them being discharged. ${ }^{8}$ Many others caught up in the fighting appear to have been troubled by their lack of an appropriate response to such scenes and actions, and some even seem to have enjoyed the experience. 9 Off the record amongst their comrades in prisoner-of-war camps, soldiers of the Wehrmacht regularly referred to the industrial-scale killing they had witnessed or participated in with matter-offactness and bravado, appearing to view it as their 'job' in the extraordinary conditions of a war, protected and encouraged by the dynamics of their combat group and the wider institution and rules of the army. ${ }^{10}$ When these same soldiers went home after 1945, however, a significant number of them suffered psychiatric disorders or difficulty coming to terms with their wartime experiences. ${ }^{11}$ These varied responses to the Second World War overlapped and conflicted with the selection of acceptable and suppression of unacceptable memories of soldiers as 'victims' in the West German public sphere. ${ }^{12}$ Similar 'amnesia' was displayed by Soviet troops 
returning from the fighting front after 1945, anxious not to disturb the perceived moral norms of the home front and the mythology of a patriotic war through frank disclosures of atrocities. ${ }^{13}$ Troops and civilians who had faced death and wounding or who had witnessed or carried out acts of extreme brutality and destruction often seem to have found it difficult to explain what they had experienced and to adjust to peacetime. ${ }^{14}$ 'Those who haven't lived through the experience may sympathise as they read, the way one sympathises with the hero of a novel or a play,' wrote one German soldier after the Second World War, 'but they certainly will never understand, as one cannot understand the inexplicable.'15 Only those affected could really comprehend what had occurred, yet many were unable - for a multitude of political and psychological reasons - to articulate their experiences. Franz Marc, a German expressionist painter and a volunteer in the First World War, famously said, just before he was killed in 1916, that he could not talk about the war, which was 'beyond belief', but he felt compelled to do so. ${ }^{16}$ It was in this context of silence, mysteries and myths that artists and writers attempted to make sense of war.

Artists' fascination with violence before the outbreak of war is well documented. It was especially pronounced before the First World War, informing Ludwig Meidner's cityscapes (for instance Apocalyptic Landscape and Burning City, both completed in 1912) and Max Beckmann's interest in the Messina earthquake of 1908 (Scene from the Destruction of Messina, 1909), in which 84,000 people had perished, and in the shipwreck of the Titanic in 1912 (The Sinking of the Titanic, 1913). ${ }^{17}$ 'The lividness of a threatening storm and yet all of pulsating carnal life, a new, even richer variation of violet, red and pale yellow-gold' was imagined in the painting, wrote Beckmann of his depiction of Messina, which showed the terrifying struggle for life of the inhabitants of the city, and convicts escaping from a ruined jail and committing acts of rape, amidst the awe-inspiring natural power of the earthquake itself: 'A rustling richness, like spreading out a lot of heave silk, and savage, cruel, glorious life.' ${ }^{18}$ For Beckmann, Meidner, Marc and other expressionists, violence could be imagined as a destructive form of Nietzschean creativity, or 'a great destruction with an objective effect, ... also a song of praise, complete and separate in its sound, just like a hymn to new creation which follows the destruction'.19 When a British collector asked during the First World War whether Kandinsky had anticipated the conflict in his works, he replied, 'Not this war, but I knew that a terrible struggle was taking place in the spiritual sphere, and that allowed me to paint the picture [Composition VII, 1913] that I sent to you.'20

Struggle and violence were idealized, in some cases in a religious sense and in others in a secular or mechanical one, as had been intimated in the 'Manifesto of Futurism' (1909):

1. We intend to sing the love of danger, the habit of energy and fearlessness.

2. Courage, audacity, and revolt will be essential elements of our poetry. 
3. Up to now literature has exalted a pensive immobility, ecstasy, and sleep. We intend to exalt aggressive action, a feverish insomnia, the racer's stride, the mortal leap, the punch and the slap.

4. We affirm that the world's magnificence has been enriched by a new beauty: the beauty of speed. A racing car whose hood is adorned with great pipes, like serpents of explosive breath - a roaring car that seems to ride on grapeshot is more beautiful than the Victory of Samothrace.

5. We want to hymn the man at the wheel, who hurls the lance of his spirit across the Earth, along the circle of its orbit.

6. The poet must spend himself with ardour, splendour, and generosity, to swell the enthusiastic fervour of the primordial elements.

7. Except in struggle, there is no more beauty. No work without an aggressive character can be a masterpiece. Poetry must be conceived as a violent attack on unknown forces, to reduce and prostrate them before man.

8. We stand on the last promontory of the centuries! ... Why should we look back, when what we want is to break down the mysterious doors of the Impossible? Time and Space died yesterday. We already live in the absolute, because we have created eternal, omnipresent speed.

9. We will glorify war - the world's only hygiene - militarism, patriotism, the destructive gesture of freedom-bringers, beautiful ideas worth dying for, and scorn for woman.

10. We will destroy the museums, libraries, academies of every kind, will fight moralism, feminism, every opportunistic or utilitarian cowardice.

11. We will sing of great crowds excited by work, by pleasure, and by riot; we will sing of the multi-coloured, polyphonic tides of revolution in the modern capitals; we will sing of the vibrant nightly fervour of arsenals and shipyards blazing with violent electric moons; greedy railway stations that devour smoke-plumed serpents; factories hung on clouds by the crooked lines of their smoke; bridges that stride the rivers like giant gymnasts, flashing in the sun with a glitter of knives; adventurous steamers that sniff the horizon; deep-chested locomotives whose wheels paw the tracks like the hooves of enormous steel horses bridled by tubing; and the sleek flight of planes whose propellers chatter in the wind like banners and seem to cheer like an enthusiastic crowd. ${ }^{21}$

A 'love of danger and heroism in daily life', wrote Filippo Tommaso Marinetti in the manifesto, rested on artists' 'disgust at the quiet life'.22

What happened when such idealistic expectations met the realities of industrialized warfare? Some, like Marc, maintained a millenarian hope of renewal and redemption into 1915:

What is war other than the prevailing condition of peace in another, more truly actual form ... Whether men die on the battlefield or in the stifling atmosphere of the mine pits, there is no essential difference. Death and its wounds do not corrupt the soul. I do not really envision death as destruction ... perhaps you remember how I had earlier spoken about death; it is absolute deliverance. ${ }^{23}$ 
Others, such as Beckmann, probably suffered a nervous breakdown. ${ }^{24}$ 'Every day is a struggle ... a struggle with myself and with the bad dreams that whir around my head like gnats', he wrote to his wife on 9 September 1915: 'Work always helps me get away from my various attacks of persecution mania (Verfolungswahn), but I often have no opportunity to work and it will be a long time before things will be decided.'25 Most artists who experienced war directly, however, seem to have become at once hardened and sensitized to it. Otto Dix, later a leading exponent of Neue Sachlichkeit in the 1920s, revealed the extent of the ambiguity, admitting - in an interview in the 1960 s - that 'war was a horrible thing' and that 'there was something tremendous about it' at the same time: 'You have to have seen human beings in this unleashed state to know what human nature is.' ${ }^{26}$ For Dix, thirty years after the event, 'you have to see things the way they are': 'That doesn't mean saying yes to war, but to a fate that approaches you under certain conditions and in which you have to prove yourself. Abnormal situations bring out all the depravity, the bestiality of human beings'. ${ }^{27}$ War had altered such artists' conceptions of violence.

The clash of heroic and deceptive official narratives and citizens' own horrific, if also extremely diverse, experiences of modern wars helped to make these wars a compelling subject for artists, writers and other observers. ${ }^{28}$ 'The impressive emotion in Catch-22 is not "black humour", the "totally absurd", ... but horror,' writes the American literary critic Alfred Kazin of Joseph Heller's unheroic war novel.29 In the aftermath of the Second World War and the early conflicts of the Cold War, it was no longer possible, Kazin concludes from his reading of Catch-22, to "describe war" in traditional literary ways'.$^{\circ}$ How, when and why writers and artists altered the form and content of their representations of conflict remain matters of dispute. Paul Fussell maintains that Heller's work continues in the tradition of the 'essentially ironic' - the 'one dominating form of modern understanding' - which had originated 'largely in the application of mind and memory to the events of the Great War' ${ }^{31}$ It was purportedly only 'the virtual disappearance during the sixties and seventies of the concept of prohibitive obscenity, a concept which has acted as a censor on earlier memories of "war", that ... is capable of revealing for the first time the full obscenity of the Great War and making 'publicly accessible' the 'literary means for adequate remembering and interpreting'. ${ }^{32}$ Some historians and critics contend that the First World War confirmed a radical break, 'the destruction of civilization and reason', pushing 'modernists' towards iconoclasm and making them 'feel the need for something stricter', in T. S. Eliot's words, as 'a way of controlling, of ordering, of giving a shape and significance to the immense panorama of futility and anarchy which is contemporary history'.33 Others, such as Jay M. Winter, have argued that romantic, spiritual and religious motifs and beliefs continued to offer solace and hope of redemption after the coming biblical apocalypse. 34 Thus, even anti-war literature like Erich Maria Remarque's Im Westen nichts Neues (1929) could be read as a Bildungsroman; Ernest Hemingway's A Farewell to Arms (1929) as a self- 
contradictory love story, 'masking and protecting a war story from the truth of its own violence'; and Henri Barbusse's Le Feu (1917) as a biblical tale of a flood and a new beginning through the abolition of war:

I shall never forget the look of those limitless lands wherefrom the water had corroded all colour and form, whose contours crumbled on all sides under the assault of the liquid putrescence that flowed across the broken bones of stakes and wire and framing; nor, rising above those things amid the sullen Stygian immensity, can I ever forget the vision of the thrill of reason, logic and simplicity that suddenly shook these men like a fit of madness. 35

Only 'after Hiroshima and Auschwitz', claims Winter, did 'the earlier commemorative effort' become impossible: 'As Julia Kristeva has observed, the Second World War undermined the very symbols through which meaning - any meaning - could be attached to the "cataclysm" of war. ${ }^{36}$

\section{Feeling, seeing and representing injury and death}

What had become audible and visible, although neither uniform nor dominant, before 1945, it can be held, were a series of publicly articulated doubts about modern warfare. Was it true, wrote Virginia Woolf to an unnamed male lawyer in Three Guineas (1938), that men and women viewed war differently? When 'we look at the same photographs' of the Spanish Civil War, do 'we feel the same things'? 37 'This morning's collection contains the photograph of what might be a man's body, or a woman's; it is so mutilated that it might, on the other hand, be the body of a pig,' she goes on. 'But those certainly are dead children, and that undoubtedly is the section of a house.' ${ }^{8}$ Everyone faced with such images would react with 'horror and disgust', demanding that 'war must be stopped', as an 'abomination' and a 'barbarity'.39 Even right-wing novelists like Ernst Jünger, who came to remythologize war, accepted that soldiers' wounds were 'senseless' and that battle could create 'indescribable feelings of isolation'. ${ }^{\circ}$ For Louis-Ferdinand Céline in Voyage au bout de la nuit (1932), troops had been 'caught, like rats in a trap', being produced as 'heroes in series' in accordance with what, in Goethe's time, had been 'this brand-new fiction of patriotism'. ${ }^{41}$ Although they rarely questioned the war effort openly, authors taking part in earlier conflicts, such as Felix Dahn in 1870, had shared a similar disgust as they contemplated the charred and dismembered bodies of the battlefield and were overcome by nausea of 'the most extreme kind' at 'the smell of blood and suppurating wounds'.42 'That war makes warriors wild, that it unfetters the sleeping, ravenous animal in humanity can and should not be denied,' confessed the German novelist. 43 Despite censorship, which prohibited sexual and scatological references more than detailed and gruesome depictions of violence, maiming and death, poets, playwrights and especially novelists, who were able to deploy the tropes of war memoirs and diaries, evoked graphic and shocking impressions of combat.44 From feelings and expressions of disgust, many writers - including traditional defenders of 'civilization' like Edith Wharton - were moved to contemplate the futility of war. 45 
Many artists expected the First World War to be a violent vortex - as can be seen in Dix's early and quite positive works (for instance Self-Portrait as a Soldier, 1914, and Self-Portrait as Mars, 1915) - but also to be a war of values, a clash of national cultures and ideologies, not of material. Very soon, however, the machine (matériel) came to dominate the war, at the expense of declared sets of values, issuing in what has been called 'rationalised slaughter' in all combatant countries and affecting all European artists' interpretations of combat. ${ }^{6}$ Soldiers were sometimes depicted as extensions of their weapons (Dix, Charging Infantryman, 1916) or as prosthetic machines themselves (Dix, War Cripples, 1920); more often, they were perceived as defenceless victims of machines. One of the points of Dix's War Cripples, in which disabled victims are paraded in a line, is to show the defencelessness of human flesh against the hard metal of the machine: shrapnel tears up flesh as if it were meat in butcher's shop - as the war showed, for the first time, to a public which had become more and more squeamish about blood, flesh and violence before 1914.47 In other words, the war had uncovered the beast in humanity in the double sense of humans as meat and humans as cruel and barbaric perpetrators. Accordingly, Dix's famous triptych Der Krieg (1929-32) portrayed a mass of anonymous troops in the left-hand panel but showed them as severed, melted-down and putrefying flesh in the other panels. ${ }^{48}$ Dix, George Grosz, Karl Hubbuch, Christian Rohlfs, Heinrich Maria Davringhausen and others set out to expose such 'bestiality', partly - perhaps even primarily - because they were angry at the effects of war. 49

Life went on, notwithstanding the dehumanizing material effects of technology and mechanization, but it had become purposeless, a form of meaningless Darwinian vitality rather than a creative Nietzschean one. Individuals seemed to be threatened with destruction, or they appeared to be condemned to endless and often pointless suffering. The former fate befell Ernst Ludwig Kirchner during the First World War itself, so that he came to stand for the subsequent 'death of Expressionism' for many critics.50 In Self-Portrait as a Soldier (1915), the founder of Die Brücke is shown with his painting hand amputated, signalling his creative impotence; in Artillerymen (1915), he cowers before a group of young soldiers in the showers, reduced to fear and shame. ${ }^{51}$ The other fate - being condemned to endless and pointless suffering - was best exemplified by the transition in Beckmann's work, for by the end of the war the former Nietzschean, who had believed at the start of the conflict that 'the more often you die, the more intensely you live', had come to question the possibility of transcendence, or the passage from this world of flesh and falsity to another world of spirit and truth..$^{2}$ Here, a contrast is to be made between the Resurrection of 1909 and the uncompleted Resurrection of 1916-18. In the first, there was no God, demons or angels, but the figures were rising towards a glorious light, with those ascending more beautiful and vital than those watching on the ground, including the artist and his own family. The vertical format was designed to match the idea of ascension. In the second, the horizontal format hints at the 
impossibility of rising anywhere; instead, individuals wander aimlessly and tormented across the plain, which looks like a battlefield. The light is now dispersed, without a source and with shadows cast in all directions. The overall impression is chaotic, with figures twisted and contorted in a medieval dance of death, entangled and in pain.53 In contrast to the earlier work, the family of the painter look out on an inescapable fate of nothingness in death and a lack of meaning, leading to madness 54

Doubts about war were reinforced by the increasingly uncompromising character of images, which in the twentieth century gradually became as explicit as literary texts. As Woolf pointed out in Three Guineas,

those photographs are not an argument; they are simply a crude statement of fact addressed to the eye. But the eye is connected to the brain; the brain with the nervous system. That system sends its messages in a flash through every past memory and present feeling. When we look at those photographs some fusion takes place within us; however different the education, the traditions behind us, our sensations are the same; and they are violent. 55

From the American Civil War onwards, photography had begun to expose the realities of war, subjecting the corpses and disorder of battlefields to the harsh light of the lens and undermining the embellishments and narrative structure of military paintings. ${ }^{6}$ Pictures such as Timothy O'Sullivan's 'Harvest of Death, Gettysburg' showed dead soldiers on a rain-drenched field, days after the battle, for the first time. 57 The progress of photographic realism was certainly not linear: the most famous photographer of the Civil War, Mathew B. Brady, was ruined by his inability to sell realistic images of the war, yet it did establish itself during the late nineteenth and early twentieth centuries, being used as a propaganda weapon by both sides in the Paris Commune, for instance when the government released pictures of twelve executed Communards in their open coffins after the insurrection had been quashed..$^{8}$ Around 1900 photographs began to appear regularly in mass-circulated illustrated newspapers. Thus, by the 1920s, in the context of this transition from the printed word to published images (and under the Weimar Republic's liberal censorship laws), it proved possible for Ernst Friedrich, a conscientious objector, to publish Krieg dem Kriege! (1924), which contained more than 180 photographs from military and medical archives, including 24 close-up shots of gaping facial wounds. 59

With the artists of the expressionist, cubist, Dada, constructivist, Neue Sachlichkeit and surrealist movements combining such photographs with newspaper clippings, artefacts, caricature and the techniques of naturalism and hyperrealism to create explicit parodies and exposés of violence during peace and war, the boundaries of a mediatized world of art, reportage and advertising in magazines, radio, newsreels and feature films appeared to have become blurred. ${ }^{60}$ The war did not turn artist-soldiers into 'realists', Marc had written to his wife on 12 September 1914, but it did confront them with 'reality' or, at least, its fragments. ${ }^{61}$ In Berlin and Zurich, in what - in Switzerland - Hans Richter termed 'the peaceful, dead-centre of the war', Dadaists 'cut up photographs, stuck them together in provocative ways, 
added drawings, cut these up too, pasted in bits of newspaper, or old letters, or whatever happened to be lying around, to confront a crazy world with its own image'.62 For Raoul Hausmann, the principal founder of the Berlin group, Dadaists 'were the first to use photography to create, from often totally disparate spatial and material elements, a new unity in which was revealed a visually and conceptually new image of the chaos of an age of war and revolution'.63 Grosz contested Hausmann's claim to have invented photomontages of this kind, contending that 'Johnny Heartfield and I' had done so in Heartfield's studio 'at the south end of the town at five o'clock on a May morning' in 1916, but his description of the purpose and procedure of montage was similar:

On a piece of cardboard we pasted a mischmasch of advertisements for hernia belts, student song-books and dog food, labels from schnaps- and wine-bottles, and photographs from picture papers, cut up at will in such a way as to say, in pictures, what would have been banned by the censors if we had said it in words. In this way we made postcards supposed to have been sent home from the Front, or from home to the Front. This led some of our friends, Tretjakoff among them, to create the legend that photomontage was an invention of the 'anonymous masses'. What did happen was that Heartfield was moved to develop what started as an inflammatory political joke into a conscious artistic technique. ${ }^{64}$

Photomontage, like film, used reproductions of reality in a deliberately jumbled-up form, 'with its contrast of structure and dimension, rough against smooth, aerial photograph against close-up, perspective against flat surface', according to Hausmann, in order to question an external world which had become senseless. ${ }^{65}$ The source of this critical, meaningless juxtaposition of material, functional and representational elements, which found a wider audience through the press and advertising, was the First World War. ${ }^{66}$

Partly as a consequence of such iconoclasm and partly as a result of wider cultural and political transformations, postcards and press photos of executions, corpses, destroyed buildings and explosions, which were often still censored in the First World War and its aftermath, had become more common during the Spanish Civil War and the Second World War. ${ }^{67}$ The question now, which well-known paintings (for instance Pablo Picasso's Guernica in 1937) and popular films (G. W. Pabst's Westfront 1918, Lewis Milestone's All Quiet on the Western Front and Howard Hawks's The Dawn Patrol, all released in 1930) made more pressing, was whether depictions of pain, suffering and death should be ugly and repellent, rather than beautiful and fascinating, to avoid tacitly sanctioning a pornography of violence and the glamourizing of war. How far could fantasies of killing and wounding, which had long been a staple of war literature and art and which were becoming part of war photography and cinema, legitimize violent acts and even atrocities in wartime? These are some of the questions addressed by Sontag in Regarding the Pain of Others. 


\section{Regarding the Pain of Others}

As Leonardo da Vinci's advice on the painting of battles - cited by Sontag - makes plain, 'the concern ... that the images to be devised won't be sufficiently upsetting', 'not concrete, not detailed enough', is an old one. ${ }^{68}$ Yet the Italian artist's insistence that his fellow painters 'make the conquered and beaten pale, and the skin above their brows furrowed with pain', also demonstrates how much has changed in a world of photography, film and television. ${ }^{69}$ Although art is based on transformation, "photography that bears witness to the calamitous and the reprehensible is much criticized if it seems "aesthetic"; that is, too much like art'.70 Some contemporaries mistakenly view 'the dual powers of photography - to generate documents and to create works of visual art' - as opposites. ${ }^{71}$ They are not, yet they remain difficult to disentangle or evaluate.

Photographs and the moving images of films 'beautify', as Sontag rightly points out, tending 'to bleach out a moral response to what is known'.72 'Often something looks, or is felt to look, "better" in a photograph,' she writes. 'Indeed, it is one of the functions of photography to improve the normal appearance of things. (Hence, one is always disappointed by a photograph that is not flattering.)' 73 These effects, in part, are formal, relying on lines, planes, contrasts and balance. They are also, in part, contextual, with the picturesque merging with the epic and adventurous traditions of warfare. ${ }^{74}$ Robert Capa, the most famous photographer of the Spanish Civil War, was therefore presented by Picture Post (founded in 1938), which presented the news through photographs alone - along with short captions - in the manner of $V u$ (1929) and Life (1936), as 'The Greatest War Photographer in the World'.75 On the magazine's cover, Capa was shown holding a camera in front of his photogenic face. The glamour of the photographer fused with the lustre of the photos themselves. ${ }^{76}$ It was later revealed that Capa's best-known photograph of the Spanish Civil War, a Republican soldier in a white shirt falling backwards to the grassy earth under the impact of a bullet, was staged, creating a graphic, aesthetically pleasing but potentially false image of the conflict.77 Until that point, it had been common to stage war photographs, as it continued to be routine to 'recreate' wars in films, because combat - if not battlefields - remained beyond the camera's scope. $7^{7}$ Even the many photographs of the First World War generally depicted the aftermath of fighting. With the production of the portable Leica 35-mm camera in 1924, which allowed thirty-six quick, close-up shots before having to be reloaded, contemporaries' expectations altered. Movie cameras, which were used in the Second World War and especially in Vietnam, had the same effect for film and television.79

The documentary expectation of photography and film has endured. It is present in the New York Times journalist John Kifner's comment that the image of 'a Serb militiaman casually kicking a dying Muslim woman in the head' in 1992 - 'one of the most enduring of the Balkan wars' - told you 'everything you need to know'. ${ }^{80}$ Earlier, in 1922, the American reporter and academic Walter Lippmann remarked on 
this, lamenting that 'photographs have the kind of authority over imagination today, which the printed word had yesterday, and the spoken word before that.' 'They seem utterly real,' he concluded. ${ }^{81} \mathrm{He}$ knew, of course, that they were not real but merely seemed to be so. This assumption about a represented - 'captured' or 'frozen' reality meant that those viewers of Capa's photograph of a dying Republican soldier who had once believed that it showed an actual incident were disappointed to discover it had been staged. It also underpins Sontag's continuing interest in the fact that 'only starting with the Vietnam War is it virtually certain that none of the bestknown photographs were set-ups', which 'is essential to the moral authority of these images'. ${ }^{82}$ Whereas 'the famous photograph of the raising of the American flag on Iwo Jima on February 23, 1945, turns out to be a "reconstruction" by an Associated Press photographer, Joe Rosenthal', the

signature Vietnam War horror-photograph from 1972, taken by Huynh Cong Ut, of children from a village that has just been doused with American napalm, running down the highway, shrieking with pain, belongs to the realm of photographs that cannot possibly be posed. ${ }^{83}$

One of the reasons for viewers' continuing willingness to take images at face value is the images' uncontrollable field, which can be framed but not filled and which gives them their potential to challenge existing narratives or expectations and to shock. Another is that images are closely connected to memory. In Sontag's opinion, 'nonstop imagery (television, streaming video, movies) is our surround, but when it comes to remembering, the photograph has the deeper bite', for 'memory freezeframes; its basic unit is the single image'. ${ }^{84}$ Consequently, 'the attack on the World Trade Center on September 11, 2001, was described as "unreal", "surreal", "like a movie", in many of the first accounts of those who escaped from the towers or watched from nearby', making 'a catastrophe that is experienced ... seem eerily like its representation'. 85 Dreams and, by extension, memories are often sequential. A shock, by contrast, requires an abrupt stop or temporal change combined with sensory veracity, indicating that the stopping - or slowing down or speeding up - is real, not imagined. Stills, whether frozen or presented as accelerated or slow-motion moving images, can achieve such an effect.

Viewers' responses to images are neither direct nor self-contained. The way they see pictures depends on context (or their physical and historical surroundings). Capa's photograph of a 'dying' Republican soldier, published by Life on 12 July 1937, was presented on the right-hand page, opposite a full-page advert for a men's hair cream, portraying a male model in a white dinner jacket with a perfect parting. ${ }^{86}$ 'Every picture is seen in some setting,' writes Sontag. 'And the settings have multiplied.' 87 The Italian clothes manufacturer Benetton was criticized in the 1990 s for using war photographs as advertising, including an image of the bloody shirt of a dead Croatian soldier, yet the wider practice of merging styles was already pervasive: 'When Capa's falling soldier appeared in Life opposite the Vitalis ad, there was a huge, unbridgeable difference in look between the two kinds of photographs, 
"editorial" and "advertising". Now there is not.' 88 What is more, the historical - not merely aesthetic and physical - context of imagery militates against viewers' ability to 'see' and be shocked by images. Although 'public attention is steered by the attentions of the media' ('which means, most decisively, images'), tying the 'CNN effect' to a 'feeling that something had to be done about the war in Bosnia' for example, 'in a world saturated, no, hyper-saturated with images, those that should matter have a diminishing effect: we become callous'. ${ }^{89}$ In the end, the New York essayist concludes, 'such images just make us a little less able to feel, to have our conscience pricked'.90

We are at once drawn towards, entertained by, repelled by and bored by images of warfare. In so far as they present us with unstaged pictures of injury and death, which remain unfamiliar (but are becoming less and less so), we are shocked, sensing the pain of those depicted and confronting their extinction (and our own). At the same time, we are attracted to such images, Sontag notes, revealed amongst other things by the slowing down of traffic 'going past a horrendous car crash', which is not motivated merely by curiosity but by 'the wish to see something gruesome'. ${ }^{11}$ Our prurience is complex, resting on the 'pornography' of 'the violation of an attractive body' and, for Georges Bataille, on 'a mortification of the feelings and a liberation of tabooed erotic knowledge', which was 'rooted in religious thinking', connecting 'pain to sacrifice, sacrifice to exaltation'. ${ }^{2}$ We make sense of these images by association, comparing them - or what they seem to portray - to our own feelings, experiences and memories, which themselves imply the 'ethical act' of remembering and the inescapable 'heartlessness' of amnesia (since absence and death are unbearable). 93 Any understanding of them necessitates historical analysis of viewers' contingent responses as well as their creators' intentions and the means of production and dissemination. Sontag's non-stop feed of images, as news and as art, is an historical peculiarity, increasing unevenly over the course of the last two centuries and eliciting varying responses in different circumstances. In this sense, the immediacy of the image can only be studied over a period of time. 


\footnotetext{
${ }^{1}$ Susan Sontag, Regarding the Pain of Others (New York: Picador, 2003), p. 18.

${ }^{2}$ Ibid. pp. 18-19.

${ }^{3}$ Arthur Ponsonby, Falsehood in War-Time: Propaganda Lies of the First World War (London, 1928).
}

Gary Messinger, British Propaganda and the State in the First World War (Manchester: Manchester University Press, 1992), pp. 1-24. See also Peter Buitenhaus, The Great War of Words: Literature as Propaganda, 1914-1918 and After (London: Batsford, 1989); Alice G. Marquis, 'Words as Weapons: Propaganda in Britain and Germany during the First World War', Journal of Contemporary History, 13 (1978), pp. 467-98; Anne Lipp, Meinungslenkung im Krieg: Kriegserfahrungen deutscher Soldaten und ibre Deutung, 1914-1918 (Göttingen: Vandenhoeck \& Ruprecht, 2003); David Welch, Germany, Propaganda and Total War, 1914-1918 (London: Athlone, 2000); David Welch, The Third Reich: Politics and Propaganda (London: Routledge, 1993), pp. 117-56; and Michael Balfour, Propaganda in War, 1939-1945: Organisations, Policies and Publics in Britain and Germany (London: Routledge, 1979).

${ }^{4}$ Joanna Bourke, The Second World War: A People's History (Oxford: Oxford University Press, 2001), p. 2, gives the proportion of civilian deaths in the First World War as 5 per cent; Richard Bessel, Violence: A Modern Obsession (London: Simon \& Schuster, 2015), p. 141, amongst others, has contested this figure, which he claims relates to the Western Front, claiming that 'civilians comprised perhaps a third of the dead of the 1914-1918 conflict'.

${ }^{5}$ The literature on soldiers' and civilians' memories of war, public commemoration and remembrance, and the writing of history is now extensive, going well beyond the early distinctions of Pierre Nora, 'Between Memory and History: Les Lieux de Mémoire', Representations, 60 (1989), pp. 7-24. See Alice Fahs and Joan Waugh (eds), The Memory of the Civil War in American Culture (Chapel Hill: University of North Carolina Press, 2004); Paul Fussell, The Great War and Modern Memory (Oxford: Oxford University Press, 1975); Paul Fussell, Wartime: Understanding and Behaviour in the Second World War (Oxford: Oxford University Press, 1989); George L. Mosse, Fallen Soldiers: Reshaping the Memory of the World Wars (Oxford: Oxford University Press, 1990); Jay M. Winter, Sites of Memory, Sites of Mourning (Cambridge: Cambridge University Press, 1995); Jay M. Winter, Remembering War: The Great W ar between Memory and History in the Twentieth Century (New Haven, CT: Yale University Press, 2006); Daniel Chirot et al. (eds), Confronting Memories of World War II: European and Asian Legacies (Seattle: University of Washington Press, 2014); Rana Mitter, 'China in World War II: Experience, Memory and Legacy', Modern Asian Studies, 45 (2011), pp. 225-40; Robert G. Moeller, W ar Stories: The Search for a Usable Past in the Federal Republic of Germany (Berkeley: University of California Press, 2001); William Niven (ed.), Germans as Victims:

Remembering the Past in Contemporary Germany (Basingstoke: Palgrave Macmillan, 2006); Christopher Browning, Collected Memories: Holocaust History and Postwar Testimony (Madison: University of Wisconsin Press, 2003); Henri Rousso, The Vichy Syndrome: History and Memory in France since 1944 (Cambridge, MA: Harvard University Press, 1994); and Mark Mazower, 'The Cold War and the Appropriation of Memory: Greece after Liberation', in Istvan Deák et al. (eds), The Politics of Retribution in Europe: World War II and its Aftermath (Princeton, NJ: Princeton University Press, 2000), pp. 212-32. 
${ }^{6}$ The nature and scope of the effects are disputed, but their existence has not been challenged: Ben Shephard, W ar of Nerves: Soldiers and Psychiatrists, 1914-1994 (London: Jonathan Cape, 2002); Edgar Jones and Simon Wessely, From Shell Shock to PTSD: Military Psychiatry from 1900 to the Gulf War (New York: Psychology Press, 2005); Joanna Bourke, 'The Emotions in War: Fear and the British and American Military', Historical Research, 74 (2001), pp. 314-30; Ted Bogacz, 'War Neurosis and Cultural Change in England, 1914-1922: The Work of the War Office Committee of Enquiry into "Shell-Shock", Journal of Contemporary History, 24 (1989), pp. 227-56; Peter Leese, Shell Shock: Traumatic Neurosis and the British Soldiers of the First World War (New York: Palgrave, 2002); Paul Lerner, Hysterical Men: War, Psychiatry and the Politics of Trauma in Germany, 1890-1930 (Ithaca, NY: Cornell University Press, 2003); Ulrich Linse, 'Das wahre Zeugnis: Eine psychohistorische Deutung des Ersten Weltkriegs', in Klaus Vondung (ed.), Kriegserlebnis: Der Erste Weltkrieg in der literarischen Gestaltung und symbolischen Deutung der Nationen (Göttingen:

Vandenhoeck \& Ruprecht, 1980), pp. 262-72; Robert H. Ahrenfeldt, Psychiatry in the British Army in the Second World War (London: Routledge and Kegan Paul, 1958); Elizabeth Roberts-Pedersen, "A Weak Spot in the Personality? Conceptualising "War Neurosis" in British Medical Literature of the Second World War', Australian Journal of Politics and History, 58 (2012), pp. 408-20; Terry Copp and Bill McAndrew, Battle Exhaustion: Soldiers and Psychiatrists in the Canadian Army, 19391945 (Montreal: McGill-Queen's University Press, 1990); Robert Anderson, Neuropsychiatry in World War II (Washington, DC: Office of the Surgeon General Department, 1966); and David Marlowe, Psychological and Psychosocial Consequences of Combat and Deployment (Santa Monica, CA: Rand, 2000).

${ }^{7}$ Alexander Watson, Enduring the Great War: Combat, Morale and Collapse in the German and British Armies, 1914-1918 (Cambridge: Cambridge University Press, 2008), pp. 241-2: the figures for Britain are extrapolated from various separately listed categories. Both sets of official figures are almost certainly too low.

${ }^{8}$ Paul Wanke, 'American Military Psychiatry and its Role among Ground Forces in World War II', Journal of Military History, 63 (1999), pp. 127-46 (p. 127).

${ }^{9}$ See especially Joanna Bourke, An Intimate History of Killing: Face to Face Killing in Twentieth-Century Warfare (London: Granta Books, 1999).

${ }^{10}$ Sönke Neitzel and Harald Welzer, Soldaten: Protokolle vom Kämpfen, Töten und Sterben (Frankfurt: Fischer Taschenbuch, 2011), pp. 391-430. The soldiers' conversations were secretly recorded by the British and Americans.

${ }^{11}$ Svenja Goltermann, Die Gesellschaft der Überlebenden: Deutsche Kriegsheimkehrer und ibre Gewalterfahrungen im Zweiten Weltkrieg (Munich: Pantheon, 2011), pp. 47-162.

${ }^{12}$ Moeller, War Stories, pp. 1-50; and Moeller, 'Germans as Victims? Thoughts on a Post-Cold War History of World War II's Legacies', History and Memory, 17 (2005), pp. 145-94.

${ }^{13}$ Catherine Merridale, 'Culture, Ideology and Combat in the Red Army, 1939-45', Journal of Contemporary History, 41 (2006), pp. 305-24; see also Catherine Merridale, Ivan's War: The Red Army, 1939-45 (London: Faber, 2005).

${ }^{14}$ Amongst other treatments, see Simon Wessely, 'Twentieth-Century Theories on Combat Motivation and Breakdown', Journal of Contemporary History, 41 (2006), pp. 269-86; and Eric Leed, 'Fateful Memories: Industrialized War and Traumatic Neuroses', Journal of Contemporary History, 35 (2000), pp. 85-100. 
${ }^{15}$ Quoted in Samuel Hynes, The Soldiers' Tale (London: Pimlico, 1997), p. 2.

${ }^{16}$ Franz Marc, 'In War's Purifying Fire', in Victor H. Miesel (ed.), Voices of German Expressionism (Englewood Cliffs, NJ: Prentice-Hall, 1970), p. 160.

${ }^{17}$ Matthias Eberle, World War I and the Weimar Artists: Dix, Gros\%, Beckmann, Schlemmer (New Haven, CT: Yale University Press, 1985), pp. 1-21, 73-105.

${ }^{18}$ Ibid.

${ }^{19}$ Vassily Kandinsky, Reminiscences (1913), quoted in D. E. Gordon, Expressionism: Art and Idea (New Haven, CT: Yale University Press, 1987), p. 15.

${ }^{20}$ Quoted in Rose-Carol Washton Long, Kandinsky: The Development of an Abstract Style (Oxford: Clarendon, 1980), pp. 25, 101.

${ }^{21}$ Filippo Tommaso Marinetti, 'Manifesto of Futurism' (1909), in Umbro Apollonio (ed.), Documents of Twentieth-Century Art: Futurist Manifestos (New York: Viking, 1973), pp. 19-24.

${ }^{22}$ Marinetti, 'Manifesto of Futurism', in Ibid.

${ }^{23}$ Quoted in Frederick S. Levine, The Apocalyptic Vision: The Art of Franz Marc as German Expressionism (New York: Harper \& Row, 1979), p. 168. See also Klaus Lankheit and Uwe Steffen (eds), Letters from the War: Franz Marc, new edn (New York: Peter Lang, 1992).

${ }^{24}$ This is the claim made by Joan Weinstein, 'Expressionism in War and Revolution', in Stephanie Barron and Wolf-Dieter Dube (eds), German Expressionism: Art and Society (London: Thames \& Hudson, 1997), pp. 35-44 (p. 37).

${ }^{25}$ Quoted in Barbara Copeland Buenger, 'Max Beckmann in the First World War', in Rainer Rumold and O. K. Werckmeister (eds), The Ideological Crisis of Expressionism: The Literary and Artistic War Colony in Belgium, 1914-1918 (London: Camden House, 1990), pp. $237-75$ (252).

${ }^{26}$ Quoted in Richard Cork, “'A Murderous Carnival”: German Artists in the First World War', in Bernd Hüppauf (ed.), War, Violence and the Modern Condition (Berlin: De Gruyter, 1997), p. 242. ${ }^{27}$ Quoted in Eberle, World War I, p. 42.

${ }^{28}$ On the persistence of heroic war literature, distributed to the troops by the army, see Wolfgang G. Natter, Literature at War, 1914-1940: Representing the Time of Greatness in Germany (New Haven, CT: Yale University Press, 1999).

${ }^{29}$ Alfred Kazin, Bright Book of Life (Boston: Little, Brown, 1973), p. 84.

${ }^{30}$ Ibid. p. 84.

${ }^{31}$ Fussell, The Great War, p. 35.

32 Ibid. p. 334.

${ }^{33}$ The quotation on the destruction of civilization is from Malcolm Bradbury and James McFarlane, 'The Name and Nature of Modernism', in Bradbury and McFarlane (eds), Modernism, 1890-1930 (London: Penguin, 1976), pp. 19-56; the other quotations are from T. S. Eliot, 'Ulysses, Order and Myth', in Frank Kermode (ed.), Selected Prose of T. S. Eliot (New York: Harcourt Brace Jovanovich, 1975), pp. 177-8 (p. 177). See also Raymond Williams, 'When was Modernism?', in The Politics of Modernism (London: Verso, 1989), pp. 31-6.

${ }^{34}$ Winter, Sites of Memory, pp. 117-229.

${ }^{35}$ Barbusse, quoted in ibid. p. 185. On Remarque, see Elizabeth Krimmer, The Representation of War in German Literature from 1800 to the Present (Cambridge: Cambridge University Press, 2010), pp. 6, 88-106; on Hemingway, see Margot Norris, 'The Novel as War: Lies and Truth in Hemingway's A Farewell to Arms', Modern Fiction Studies, 40 (1994), pp. 689-710. See also Ted 
Bogacz, "A Tyranny of Words": Language, Poetry and Antimodernism in England in the First World War', Journal of Modern History, 58 (1986), pp. 643-68.

${ }^{36}$ Winter, Sites of Memory, p. 9.

${ }^{37}$ Virginia Woolf, Three Guineas (Oxford: Blackwell, 2001), p. 10.

${ }^{38}$ Ibid. p. 10.

${ }^{39}$ Ibid. p. 10.

${ }^{40}$ Ernst Jünger, Sturm (Olten: Oltner Liebhaberdruck, 1963), p. 56; Feuer und Blut (Magdeburg: Stahlhelm, 1925), p. 16; and In Stablgewittern (Hannover: n.p., 1920), p. 93. See Roger Woods, 'The Conservative Revolution and the First World War: Literature as Evidence in Historical Explanation', Modern Language Review, 85 (1990), pp. 77-91.

${ }^{41}$ Quoted in Robert L. Sims, 'War and Myth in the Twentieth Century: Drieu la Rochelle, Céline and Claude Simon', Neophilogus, 68 (1984), pp. 179-91.

${ }^{42}$ Felix Dahn, Erinnerungen (Leipzig: Breitkopf und Härtel, 1894), vol. 4, pp. 569-70.

${ }^{43}$ Ibid. pp. 590-4.

${ }^{44}$ On the particular biases of censors, see J. H. Willis Jr, 'The Censored Language of War: Richard Aldington's Death of a Hero and Three Other War Novels of 1929', Twentieth-Century Literature, 45 (1999), pp. 467-87.

${ }^{45}$ Annette Larson Benert, 'Edith Wharton at War: Civilized Space in Troubled Times', TwentiethCentury Literature, 42 (1996), pp. 322-43. On the shift from adventurous or heroic literary visions of future war to fearful anticipation of gas attacks, aerial bombardment and, after 1945, the annihilation of humanity, already presaged by Alfred Noyes's The Last Man in 1940, see I. F. Clarke, Voices Prophesying War, 1763-1984 (Oxford: Oxford University Press, 1966), pp. 162-208. ${ }^{46}$ Daniel Pick, War Machine: The Rationalisation of Slaughter in the Modern Age (New Haven, CT: Yale University Press, 1996).

${ }^{47}$ Linda F. McCreevy, Life and Works of Otto Dix (Ann Arbor, MI: UMI Research Press, 1981), pp. 17-32.

${ }^{48}$ See especially Birgit Dalbajewa et al. (eds), Otto Dix: Der Krieg (Dresden: Sandstein, 2014); and Veit Loers, Otto Dix und der Krieg (Regensburg: Die Galerie, 1981).

${ }^{49}$ John Willett, The New Sobriety: Art and Politics in the Weimar Period, 1917-33 (London: Thames and Hudson, 1978), pp. 111-17.

${ }^{50}$ Joan Weinstein, The End of Expressionism: Art and the November Revolution in Germany, 1918-1919 (Chicago: University of Chicago Press, 1990), pp. 107-60.

${ }^{51}$ See Peter Springer, Hand and Head: Ernst Ludwig Kirchner's Self-Portrait as Soldier (Berkeley: University of California Press, 2002).

${ }^{52}$ Barbara Copeland Buenger (ed.), Max Beckmann: Self-Portrait in Words: Collected Writings and Statements, 1903-1950 (Chicago: University of Chicago Press, 1997), 140.

${ }^{53}$ Jörg Schneider, Religion in der Krise: Die bildenden Künstler Ludwig Meidner, Max Beckmann und Otto Dix meistern ibre Erfahrung des Ersten Weltkrieges (Güterslo: Gütersloher Verlagshaus, 2006).

${ }^{54}$ Hans Belting, Tradition as a Problem of Modern Art (New York: Timken Publishers, 1989).

${ }^{55}$ Woolf, Three Guineas, p. 10.

${ }^{56}$ William F. Thompson, The Image of W ar: The Pictorial Reporting of the American Civil War (Baton Rouge: Louisiana State University Press, 1994); Jan Zita Grover, 'Philosophical Maneuvers in a Photogenic War', Afterimage, 10 (1983), pp. 4-6; Jan Zita Grover, 'The First Living-Room War: 
The Civil War in the Illustrated Press', Afterimage, 11 (1984), pp. 8-11; and William A. Frassanito, Antietam: The Photographic Legacy of America's Bloodiest Day (New York: Charles Scribner's Sons, 1978).

${ }^{57}$ James D. Horan et al. (eds), Timothy O'Sullivan, America's Forgotten Photographer (New York: Doubleday, 1966).

${ }^{58}$ James A. Leith, 'The War Images Surrounding the Commune', in James A. Leith (ed.), Images of the Commune (Montreal: McGill-Queen's University Press, 1978), pp. 101-50; and Donald E. English, Political Uses of Photography in the Third French Republic, 1871-1914 (Ann Arbor, MI: UMI Research Press, 1984).

${ }^{59}$ Ernst Friedrich, Krieg dem Kriege!, new edition (Berlin: Ch. Links Verlag, 2015). Astrid Deilmann, 'Grenzen des Darstellbaren in der Fotografie: Anmerkungen zu Ernst Friedrichs “Krieg dem Kriege!” von 1924', in Raoul Zühlke (ed.), Bildpropaganda im Ersten Weltkrieg (Hamburg: Kämpfer, 2000), pp. 397-430.

${ }^{60}$ For a critique, see Clement Greenberg, 'The Pasted Paper Revolution', in J. O’Brian (ed.), The Collected Essays and Criticism (Chicago: University Chicago Press, 1993), vol. 4, pp. 61-6 (p. 65). See also Paul Wood, 'The Revolutionary Avant-Gardes: Dada, Constructivism and Surrealism', in Paul Wood (ed.), The Challenge of the Avant-Garde (New Haven, CT: Yale University Press, 1999), pp. 226-56.

${ }^{61}$ F. to M. Marc, 12 September 1914, in Lankheit and Steffen, Letters from the War, p. 4.

${ }^{62}$ Hans Richter, Dada: Art and Anti-art (London: Thames and Hudson, 1965), pp. 12, 114.

Richter was himself a young member of the Dada movement.

${ }^{63}$ Raoul Hausmann, 'Photomontage' (1931), quoted ibid. p. 116.

${ }^{64}$ Grosz, quoted in Richter, Dada, p. 117

${ }^{65}$ Hausmann, quoted in Richter, Dada, p. 116.

${ }^{66}$ See Virginia Hagelstein Marquardt (ed.), Art and Journals on the Political Front (Gainesville:

University Press of Florida, 1997), pp. 1-16, 63-99, 142-82.

${ }^{67}$ Gerhard Paul, Bilder des Krieges, Krieg der Bilder: Die Visualisierung des modernen Krieges (Munich: Schöningh, 2004), pp. 103-310.

${ }^{68}$ Sontag, Regarding the Pain of Others, p. 75.

${ }^{69}$ Quoted in ibid. p. 75.

${ }^{70}$ Ibid. p. 76.

${ }^{71}$ Ibid. p. 76.

${ }^{72}$ Ibid. p. 81.

${ }^{73}$ Ibid. p. 81.

${ }^{74}$ I have written about these traditions at greater length elsewhere: Mark Hewitson, 'On War and Peace: German Conceptions of Conflict, 1792-1815', Historical Journal, 57 (2014), pp. 447-83; Absolute War: Violence and Mass Warfare in the German Lands, 1792-1820 (Oxford: Oxford University Press, 2017); and The People's Wars: Histories of Violence in the German Lands, 1820-1888 (Oxford: Oxford University Press, 2017).

${ }^{75}$ Quoted in Sontag, Regarding the Pain of Others, p. 33.

${ }^{76}$ Phillip Knightley, The First Casualty: The War Correspondent as Hero and Myth-Maker from the Crimea to Iraq, 3rd edn (Baltimore, MD: Johns Hopkins University Press, 2004). 
${ }^{77}$ Gerhard Paul, 'Der Krieg der Fotografen: Die fotografische Kriegsberichterstattung im Spanischen Bürgerkrieg 1938-1939', in Ute Daniel (ed.), Augenzeugen: Kriegsberichterstattung vom 18. zum 21. Jabrbundert (Göttingen: Vandenhoeck \& Ruprecht, 2006), pp. 141-68 (p. 157). See also Sigrid Schneider, 'Manipulating Images: Photojournalism from the Spanish Civil War', in Luis Costa et al. (eds), German and International Perspectives on the Spanish Civil War: The Aesthetics of Partisanship (New York: Camden House, 1992), pp. 179-97.

${ }^{78}$ John Hannavy (ed.), The Camera Goes to War: Photographs from the Crimean War, 1854-56 (Edinburgh: Scottish Arts Council, 1974); Ulrich Keller, The Ultimate Spectacle: A Visual History of the Crimean War (Amsterdam: Gordon and Breach, 2001); and André Rouillé, 'Ein photographisches Gefecht auf der Krim', in Stefan Germer and Michael Zimmermann (eds), Bilder der Macht - Macht der Bilder: Zeitgeschichte in Darstellungen des 19. Jabrbunderts (Munich:

Klinkhardt \& Biermann, 1997), pp. 361-70.

${ }^{79}$ Paul, Bilder des Kriegs, pp. 225-324.

${ }^{80}$ Quoted in Sontag, Regarding the Pain of Others, p. 90.

${ }^{81}$ Quoted in ibid. p. 25.

${ }^{82}$ Ibid. p. 57.

${ }^{83}$ Ibid. pp. 56-7.

${ }^{84}$ Ibid. p. 22.

${ }^{85}$ Ibid. pp. 21-2.

${ }^{86}$ Ibid. pp. 32-3.

${ }^{87}$ Ibid. p. 120.

${ }^{88}$ Ibid. p. 120.

${ }^{89}$ Ibid. pp. 104-5.

${ }^{90}$ Ibid. p. 105.

${ }^{91}$ Ibid. pp. 95-6.

${ }^{92}$ Ibid. pp. 95, 98-9.

${ }^{93}$ Ibid. p. 115. 